\title{
Postwar Popular Politics: Integrating the Voice of the People in Postwar Political History
}

\author{
Harm Kaal and Vincent van de Griend
}

\section{Introduction}

Both inside and outside of academia, a declining trust in politicians and the rise of populism has catalysed a debate about a supposed "crisis of democracy."1 Political decision-making has increasingly escaped public control, particularly at the level of the European Union. The public sphere spiralled into decline when citizens turned into passive consumers who focused on private instead of public concerns. ${ }^{2}$ Moreover, with the laws and mechanisms of the mass media dictating political communication, parliamentary democracy has transformed into a mediacracy or drama democracy. Against this background, populist politicians have emerged on the scene, promising to restore the power of the people.

One should, however, be careful not to integrate populist notions of crisis and of confrontation between political elites and the people into the historical analysis of political representation. We argue that at the heart of the discourse of crisis is a lack of understanding of the multifaceted ways in which politicians and the people have interacted. In this chapter, which is based on a case study of the Netherlands, we first offer a reconceptualisation of the notion of popular politics by mapping the repertoire of communicative practices through which political representatives and the people they represented have interacted in the postwar years. Second, we zoom in on one of these practices: letters people sent to their representatives. The analysis will be aimed at identifying popular perceptions of political representation that were articulated in these letters. Third, we end by offering a way forward for historical research on the interaction between politicians and the people.

The vast scholarship on political representation in parliamentary democracies has been mostly oriented towards the "formal" aspects of political representation treating it as a status that results from particular political procedures and constitutional arrangements with research being dedicated to an investi-

1 Rosanvallon (2008); Saward (2010).

2 Habermas (1962). 
gation of how representatives take up their role. ${ }^{3}$ Recently, however, several scholars have introduced alternative accounts of the notion and history of political representation that allow for a more dynamic approach of the relationship between politicians and the people. One of them is the French historian and political scientist Pierre Rosanvallon. In La contre-démocratie. La politique à l'âge de la defiance, ${ }^{4}$ he attacks the "myth of the passive citizen" that is omnipresent in accounts of the recent historical trajectory of democracy and political representation. Rosanvallon brings in the notion of "counter-democracy" to show that built into the political system are practices through which citizens hold their representatives to account. He distinguishes between three mechanisms (apart from elections, which he claims are losing significance) through which the people act upon politics: surveillance (through the media, the omnipresence of public opinion, and other forms of oversight and calls for transparency), prevention (e.g. through actions of protest movements), and judgment (e.g. court cases with citizens as jurors, watchdogs, and other forms of investigation). Together they make up a "durable democracy of distrust."

Although Rosanvallon's conceptualisation of counter democracy tends towards a focus on technical and quasi-institutionalised forms of popular participation in the polity, particularly the mechanism of surveillance does offer a new perspective on the interaction between politicians and the people. In postwar democracies, politicians are continuously confronted with, and need to take into account, public opinion - "the essential manifestation of the people as an active and permanent presence"- which is presented to them through, among others, the media, opinion polls, and demonstrations. ${ }^{5}$ Surveillance also amounts to holding politicians to account in terms of their behaviour by uncovering scandals and reports on improper conduct. These durable expressions of distrust have forced politicians to offer "transparency" and to show consistency in terms of their public and private behaviour.

Where Rosanvallon has focused on unpacking the notion of democracy, political scientist Michael Saward has presented an alternative approach to political representation that centres on the concept of representative claim-making: the claim to act and speak on behalf of others. He sees representation as a

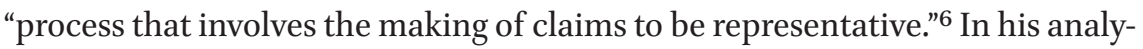
sis of the nature of political representation, Saward contests the claim of Carl Schmitt that representation is to be understood as the "realization of the unity

3 The classical study is Pitkin (1967).

4 Rosanvallon(2006), translated as: Counter-Democracy. Politics in an Age of Distrust, Rosanvallon (2008).

5 Rosanvallon (2008) 31.

6 Saward (2005) 184. 
of an authentic community." Referring to Anderson and Bourdieu, Saward contends that "[c]onstituencies, like communities, have to be 'imagined" and that politicians are engaged in the "active constitution of constituencies."

Saward makes clear that claim-making is not limited to politicians. His framework allows us to explore how representation "works," also beyond the sphere of parliament, at various levels in- and outside of what is traditionally regarded to be the "political sphere." 8 The British historian Jon Lawrence in turn has convincingly argued that the formation of political identities and constituencies - including the making of representative claims as Saward would call it - was not a top-down process. Politicians were faced with "pre-existing popular beliefs and aspirations" they needed to tap into. This brings Lawrence to a discussion of the reception of the language of politics and the need to study

The interaction between the worlds of 'formal' and informal politics, conscious that the relationship between the two is never unmediated, and that our analysis must therefore always be sensitive to the tensions and ambiguities in the relationship between 'leaders' and 'led.' ${ }^{9}$

Historians, however, have found it hard to find ways to explore politics from below. In a recent overview of the state of the art in political history the authors argue that "governments, monarchs, parties, or parliaments [...] still get the bulk of the attention."10 Lawrence himself acknowledges that a lack of sources leaves "much [...] to inference - to the critical and interpretative skills of the historian."11 As a result, popular perceptions of the political often remain to be a black box.

\section{Practices of Popular Politics}

British historians often use the term "popular politics" to refer to political communication from below, by ordinary people. Although the concept often lacks a clear definition, it is mostly used as the opposite of formal, organised (party) politics. In historiography on nineteenth century British politics, popular politics refers to the rough and tumble of uncontrolled, spontaneous, and very

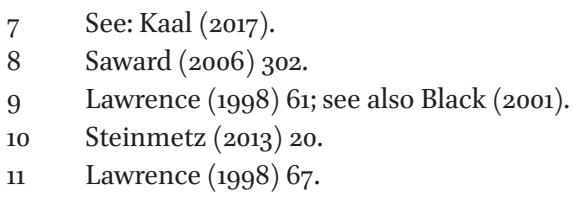


visible popular involvement in politics (and the degree to which this gradually made way for a more disciplined political culture).${ }^{12}$ Furthermore, the concept is used in studies that reflect on postwar popular political action in the form of demonstrations and manifestations initiated by social movements in the $1960 \mathrm{~s}$ and 1970 os. $^{13}$ The tendency to narrate postwar popular involvement in politics in terms of active citizenship and social movements has, however, obscured our view on other forms of popular politics that fall beyond this rather limited realm of civic engagement. Recent work by Rosanvallon, Saward, and others has shown that popular involvement in the political as a communicative space was much broader. Opening up the concept of popular politics to include the broad range of communicative practices through which the interaction between citizens and their representatives took shape might help us to overcome the tendency among political historians to still focus their studies on the history of "governments, monarchs, parties, or parliaments."14 The identification of these practices enables us to subsequently explore popular perceptions of political representation and of "the political" more in general: what did citizens expect from their representatives, what did they conceive as "good politics" at any given time? This in turn helps us to identify shifts in the norms, conventions, expectations, attitudes, and emotions that guided their interaction with politicians in the postwar years.

"Popular politics" is also a characterisation of the political culture of a particular era. British historians, for instance, have long debated the question when in the nineteenth century popular politics made way for "party politics", that is, for a more controlled, organised, and disciplined culture of popular political engagement. "Popular politics" also captures much of the political culture that developed from the late 1950s onwards. In the 1950s, in Western democracies like Britain and the Netherlands, discussions arose about a growing gap between the political (party) elites and "the people." Blame was put on the development of parties into professional organisations that had become alienated from the public at large. The traditional election meeting - with politicians delivering a speech in front of a loyal crowd of electors - was in decline: fewer people showed up and fewer meetings were held..$^{15}$ The distance that had marked the political culture of the early postwar years was now identified as a problem. Restraint, trust in the political system, and, given the recent experiences of political extremism, distrust of forms of interaction and repre-

\footnotetext{
12 Vernon (1993); Lawrence (2006) as well as earlier work by Lawrence.

13 Davis (2008); Eley (2002).

14 Steinmetz (2013) 20.

15 Lawrence (2009) 154-55.
} 
sentation that deviated from the formal institutions and procedures of parliamentary politics had been the norm and had made politics in the words of Martin Conway "neat, controlled and ever so slightly boring."16

The call to reinvigorate the relationship between politicians and the people was prompted by broader shifts in society. From the late 1950s onwards, the notion of "the people" was reconceptualised. A compartmentalisation of the people in terms of distinct social blocs gradually, but steadily, lost force. In what Bernard Manin has characterised as the era of party democracy - roughly between the late nineteenth century and the 1960s - representatives were exponents of the various social groups in society they represent: there was "sociological similarity" between them and the people they represented. In the Netherlands, sociologists used the term "pillarisation" as a metaphor for the coexistence of several socio-religious communities (pillars) that were united around a shared class or religious identity. When the ties between class, religion, and political identity formation loosened (de-pillarisation), the concept of the people became somewhat diffuse and intangible. This could potentially harm the stability of parliamentary democracy. After all, the stability and legitimacy of a representative system depends on the ability of politicians to translate the abstract notion of the people into a meaningful category to which both politicians and the people they aimed to represent could relate, a category with which voters could identify.

Rosanvallon has argued that with the demise of party democracy, representatives were no longer expected to "make present" the various groups in society, but to "be present." Being present means that representatives were expected to present themselves as in sync with the everyday experiences of citizens, with their "trials and tribulations." ${ }^{17}$ And since people identified themselves no longer primarily along lines of class or religion, but along lines of shared experiences of social, economic, material, cultural, and historical conditions, representatives who showed empathy for one citizen, were simultaneously tapping into a constituency of citizens with shared conditions. The popular politics of the late 1950 s and beyond put a bonus on those politicians who were approachable, who were willing to engage with citizens and to open themselves up from input of the people. In an attempt to be present, politicians across Western Europe started to look for new ways to interact with the people they aimed to represent. In this contribution, we first briefly map four of these practices of interaction and discuss how they can help us to explore popular perceptions of political representation. Subsequently, the remainder of this

\footnotetext{
16 Conway (2002) 59-6o.
}

17 Rosanvallon (2011) 188. 
chapter will be dedicated to one of these practices: the letters people sent to politicians.

\section{Four Practices of Interaction between Politicians and the People}

First, personal letters, and more recently emails, addressed to politicians are the communicative practice that comes closest to giving direct access to popular views. ${ }^{18}$ Politicians' personal archives bear witness to the fact that many people used it to address their representatives. Compared to demonstrations or manifestations, letter writing was a fairly easy and "safe" way to address politicians but also a significant one: politicians used letters to gauge public opinion and many made sure to send a reply. ${ }^{19}$ Although letters do not give direct access to "the mind of the people," recent research within the field of life writing has shown their importance in constructing identities-through-dialogue; ${ }^{20}$ they thus give us access to how "ordinary citizens" expressed their political identity in interaction with their representatives. Studying this form of popular politics therefore provides us crucial insights in the nature of popular conceptions of political selfhood, citizens' expectations of politicians, and in what people perceived as "political."21

Newspapers also offered a platform for the voice of the people. They published letters-to-the-editor and stimulated interaction between politicians and the people. In the run-up to general elections, Dutch newspapers, for instance, invited readers to send in questions for party leaders by mail or phone and published the politician's response a couple of days later. ${ }^{22}$ This engagement of the printed press has been characterised as a transition from a partisan logic - in which the media acted as a rather uncritical platform for political communication - towards a public logic in the 1960s, when journalists adopted a far more critical approach. ${ }^{23}$ Their increased orientation on the voice of the people might be explained by the fact that also the newspapers were looking for new ways to engage with their public. When the close ties between particular news media and socio-political communities were severed in the 196os, journalists were less sure about what kind of public they were representing. One way to solve this issue was reader research, another way was to open up

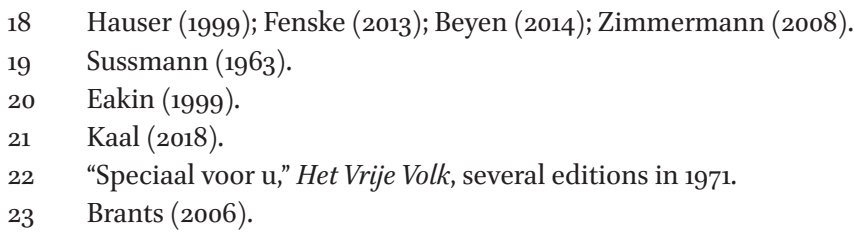


newspaper columns to the voice of the people. That said, we still know very little about the role the printed press played in offering citizens a platform for the articulation of popular views on politics.

Second, television offered an important platform for the articulation of popular views on politics and for interaction between politicians and the people. Thanks to television, the popular politics of the late 1950s and beyond was marked by a similar sense of risk and suspense as the confrontations with the general public in the late 19th century platform meetings. In Britain in the 1959 general election campaign, politicians were confronted with a very hostile studio audience in The Last Debate. ${ }^{24}$ In a similar setting, Dutch politicians answered questions from the audience in a televised debate in the 1967 campaign. In both cases, these confrontations were one-off events, at least for a long time to come. ${ }^{25}$ In slightly adapted fashion, the confrontational format however did continue to pop up in the 1960 s and 1970s. On the radio, politicians answered questions phoned-in by listeners, and in discussion programmes they discussed key issues with panels that included members of the general public. Moreover, from the 1950s onwards, politicians were also confronted with the opinion of the general public in news broadcasts. Voxpops - journalists interviewing people on radio or TV - brought "ordinary" citizens into the public limelight. From the mid-1950s onwards, voxpops were used to represent the diversity of popular opinion and thus offered opportunities for identification to the audience watching and listening at home. When they were first introduced, voxpops revealed a new appreciation of popular opinion: apparently, the opinion of members of the general public was now to be taken seriously, rather than ignored and dismissed as uninformed.

Third, opinion polls, introduced in much of Western Europe after the Second World War, resulted in a reconceptualisation of the notion of public opinion. Opinion polls represent popular opinion on political representation in that advanced scientific tools and techniques are used to construct something that could not be imagined before: "the" public opinion on particular issues. ${ }^{26}$ Its constructed nature also speaks from the fact that polling agencies formulate questions, on their own or commissioned by customers like newspapers and news networks or political parties, and deliver a particular interpretation of the results. The deconstruction of poll surveys therefore reveals what polling agencies, or their customers deemed politically relevant, but also shows how people could imagine themselves as political subjects, i.e. as members of

\footnotetext{
24 Lawrence (2009) 168-69.

25 Kaal (2014).

26 Igo (2007).
} 
a group of people who held particular views on politics. In the words of Sarah Igo, opinion polls provided us as citizens with "knowledge about ourselves." 27 It enabled people to identify themselves as members of a majority or minority, as members of particular constituencies, marked by shared demands, beliefs, and social, economic, cultural, and material conditions. Simultaneously, opinion polls and other forms of sociological research based on polls and survey data brought with it a new conceptualisation of the people as, to quote Sarah Igo once more, "anonymous, atomized individuals holding discrete views." This taken into account, polls still also provide us with unique data on popular opinion on political representation: on the conduct, actions and personality of politicians. Governments and political parties indeed treated opinion polls as a very welcome instrument to get access to the hearts and minds of the people, and to grasp the undercurrents of popular political views and sentiments. ${ }^{28}$ Their analysis is therefore a vital element of our aim to map the changing nature of popular perceptions of political representation.

Fourth and finally, popular culture, which pluralised and expanded massively throughout the post-war period, offered a new platform for interaction between politicians and the people. Media like popular magazines and TV shows of course do not merely reflect popular sentiments: they both tapped into them and informed popular views on political representation. They handed their readers and viewers a frame through which they could narrate and imagine political reality and their place within it. ${ }^{29}$ By paying attention to popular culture we are, according to Lawrence Black, putting "politics in its wider social setting." ${ }^{30}$ John Street in turn has argued that we should approach the interaction between politics and a massified and pluralised popular culture as "a legitimate part of the complex ways in which political representation functions in modern democracies". ${ }^{31}$ Political representation in this case refers to the way in which claims to power and to act and speak on behalf of others are articulated (and contested) in the public sphere. In the period under investigation, the practices and discourses of popular culture became a significant part of the repertoire through which these representative claims were articulated. Popular culture thus emerges as a communicative space in which politicians are making representative claims and in which political identities are constructed and articulated. Elements of communication that are typically associated with popular culture - looks, emotions, dress, body language, a fo-

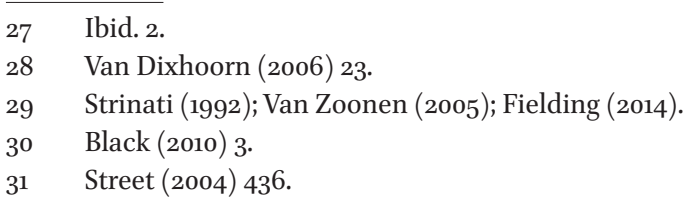


cus on the private self - therefore need to be taken seriously as crucial elements of political communication as well. ${ }^{32}$

Through these four practices - but not limited to these practices - both politicians and the people have tried to articulate what constituted political representation. Taken together, they offer an angle to explore popular ideas of political representation and to map their historical development in the postwar years.

\section{Epistolary Interaction}

Epistolary interaction formed an important element of the repertoire of interaction between politicians and the people. In the 196os, Dutch research on popular feelings of political efficacy, i.e. the "feeling that individual political action does have, or can have, an impact upon the political process," 33 showed that $5^{2}$ per cent of the population perceived writing a letter to a politician as an effective means towards solving a particular issue. Respondents had been asked to judge the effectiveness of a number of individual and collective actions, like "take matters into your own hands" (88 per cent), "joining an association" (78 per cent), "signing a petition" (59 per cent), or "writing a letterto-the-editor" (45 per cent). ${ }^{34}$ Letters addressed to politicians are part of a broader family of written popular political communication that also includes petitions and other forms of popular appeals addressed to single politicians, office holders, or institutions such as Parliament. Letters, however, stand out because of their informal nature compared to petitions and appeals which are handled according to formal procedures. ${ }^{35}$ One can even argue that personal letters addressed to politicians are a communicative practice that comes closest to giving direct access to popular views on politics. Letters provide us with sources from ordinary people, rather than the abundance of sources about them that are most often used in historical research. ${ }^{36}$

Letter writing is in itself a democratic act by citizens who are practicing their right and freedom to address politicians and to make themselves present beyond the ballot box. ${ }^{37}$ In a sense, by writing a letter, by directly addressing a representative of the people, citizens are bridging the gap between politicians

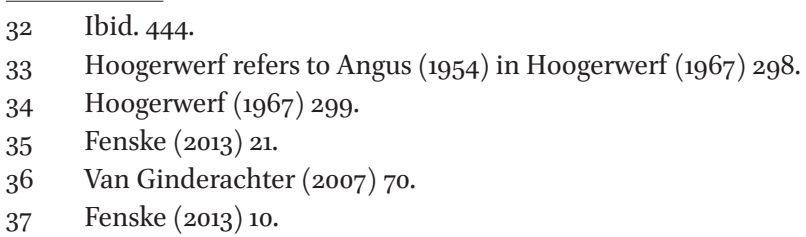


and the people that is part of the system of political representation. By reading and processing these letters, politicians are not representing the will of the people, but confronted with it. This has, however, often been ignored in historical research that merely treats these letters as exponents of clientelism. Letters are indeed part of a long tradition of interaction between rulers and ruled, going back to clientelistic exchanges in the Middle Ages and Early Modern Era. Although clientelism was also part of epistolary interaction in the postwar years, citizens also used letters to comment and reflect on the political issues of the day and on the behaviour of politicians. Moreover, as Marnix Beyen has shown, by putting pen to paper, members of the general public contributed to the politicisation of particularissues: they triggered their representatives to discuss popular concerns in Parliament. ${ }^{38}$ These letters therefore provide us with an angle to explore how the lifeworld of individual citizens became connected to the world of politics, how citizens perceived politics, how they made sense of political issues (their "political knowledge"), and the standards they used to evaluate the behaviour of their representatives.

It was not one-way traffic. Politicians, as research for Germany and the Netherlands has shown, received an increasing number of letters from members of the general public in the postwar years and took these letters very seriously. ${ }^{39}$ They of course received mail from lunatics who ventilated conspiracy theories, but most of the letters made sense. ${ }^{40}$ The Dutch social democrats developed an administrative procedure that enabled them to distribute letters to the appropriate expert within the party and made sure to send a reply. The need to treat letters seriously and to make sure that communication between citizens and government went smoothly also manifested itself in repeated discussions throughout the 196os about the speed with which citizens should receive an answer to letters sent to municipal or national authorities and the use of polite forms of address in government correspondence with citizens. ${ }^{41}$

Although people at party offices were kept busy administering and answering incoming and outgoing mail (and phone calls), much of this correspondence has not survived history. To the dismay of the head of the Dutch Public Record Office, in the early 1990 s the archive containing letters citizens had sent to their Prime Minister after 1945 was destroyed. ${ }^{42}$ Luckily, some politicians

\footnotetext{
$38 \quad$ Beyen (2014) 30.

39 Fenske (2013) 20; Van de Griend (2016).

40 The liberal party for instance kept a separate register of incoming letters from lunatics ('gekken'). National Archives of the Netherlands (NA), Archive of the VvD (2.19.022), inv. nr. 35 .

41 See for instance: "De Jong wil dat brieven sneller worden beantwoord," in Trouw, 7 March 1970.

42 NA, Archive of the Cabinet of the Prime Minister (2.03.01) 46.
} 
and most political parties have left an archive behind that contains correspondence from and with citizens.

To illustrate how an analysis of letters addressed to politicians helps us to identify popular perceptions of political representation, we introduce a case study of letters citizens sent to the Dutch Labour Party, Partij van de Arbeid (PvdA), between 1966 and 1971. In the 196os, against the background of a "party democracy" in decline, a sense of crisis captured the social democrats. ${ }^{43}$ Party leaders questioned if the socio-economic agenda of social democracy sufficiently appealed to a younger generation. Moreover, after disappointing elections in 1966, young party members voiced their dissatisfaction with the course of events within the PvdA. In order to win back popular support, this group, presenting itself under the name of Nieuw Links 'New Left', tried to achieve a democratisation, radicalisation, and rejuvenation of the party. ${ }^{44}$ This catalysed fierce debates within the party. Things settled down when New Left advocate André van der Louw was elected party chairman in 1971.

Historians have hitherto mainly approached these events from the perspective of the party elite, focusing on the clash between the "party establishment" and the newcomers of the New Left. ${ }^{45}$ The clash, however, also triggered a response by "ordinary" party members. Here we present an analysis of the letters people sent to the chairman of the PvdA Sjeng Tans (1966-1969) and Anne Vondeling (1969-1971). Our research is based on an analysis of a corpus of some two hundred letters. The vast majority of these letters was written by men, only one out of ten by a female letter writer. Moreover, more than half of these letters came from party members. Our goal is three-fold. First of all, we aim to establish how "ordinary people" experienced and responded to the developments within the party. Historians have argued that the PvdA ignored signs that many people who sympathised with the PvdA felt alienated by the impact the New Left had on "their" party. ${ }^{46}$ Second, we will use this corpus to establish more in general why people took up their pens, what they expected from the politicians they addressed, and how they conceived of themselves as political subjects. Finally, we will also address how the party responded to the input and questions they received by mail.

The majority of the letters sent to party chairmen Tans and Vondeling can be characterised as "comments." In their letters to the party, citizens commented on current events. Michaela Fenske has defined this as a form of

\footnotetext{
$43 \quad$ Kennedy (1995) 196.

$44 \quad$ Van Praag (1991) 41.

45 See Kennedy (1995).

$46 \quad$ Van Praag (1991) 75-79; Kennedy (1995) 197.
} 
'confrontation' or 'dispute' Auseinandersetzung, between citizens and their representatives. ${ }^{47}$ This suggests that these citizens were informed, that they had access to channels of political information, and were therefore able to hold their representatives to account. In the 1960s, citizens were fed with information by an increasingly pluralistic mass media landscape that, as we have argued before, was characterised by a "public logic": the mass media acted as critical watchdogs of the political elite. ${ }^{48}$ The letters provide an indication of the role the mass media played in shaping popular perceptions of politics. ${ }^{49}$ "Nothing works as clarifying as this little 'window' called television," one woman wrote. "It is as if it delivers an X-ray of people, thereby providing a lot of insights in the human character, and boy, what little of importance is left."50 Journalist and prominent social democrat Laurens ten Cate argued that the mass media contributed to turning citizens into an informed and critical audience that was no longer easily fooled. ${ }^{51}$ The letters indeed show that citizens did not hesitate to confront politicians with inconsistencies. Although politicians publicly proclaimed openness, transparency, and a democratic spirit, to some citizens this came across as a hollow slogan. "I would like to bring something to your attention, that, despite all openness, is tenaciously concealed," one citizen for example wrote regarding the national immigration policy. ${ }^{52}$ By pointing out such issues, people not merely responded to current events, but initiated the politicisation of particular themes.

Many comments concerned the impact of the New Left on the PvdA. The comments reflect the divide within the party between the older generation of social democrats and a younger generation that aimed to steer the party to the left. One group of letter writers expressed their "amazement," "agitation," and "confusion" with regard to the agenda of the New Left. Such criticism mainly concerned the New Left's sympathy for extra-parliamentary actions and the case it was making for the recognition of the communist German Democratic Republic. Many letter writers levelled their criticism against New Left frontman André van der Louw, characterising him as a "wolf in sheep's clothing"

$47 \quad$ Fenske (2013) 85.

48 Brants (2009) 9o.

49 For example: International Institute of Social History (IISH), PvdA Archive, inv.nr. 376B, letter from J.P., 2 Feb. 1971; inv.nr. 487A, letter from J.B., 6 Feb. 1967; inv.nr. 487B, letter from Mrs. de G., 25 Jan. 1967.

IISH, PvdA Archive, inv.nr. 373A, letter from family N., 18 March 1969: "niets werkt zo verhelderend als het venstertje wat T.V. heet. De mensen die ervoor komen, staan als het ware in een röntgenfoto, je leert daardoor enorm veel mensenkennis opdoen en o wat blijft er weinig reëels van over" [sic].

$5^{1} \quad$ Ten Cate (1967) 7 .

$5^{2}$ IISH, PvdA Archive, inv.nr. 367A, letter from P. van S., 18 Nov. 1966. 
and a carnivalesque figure who "killed" democracy and made politics "impossible."53 Others were also critical of the role played by the left-wing broadcasting organization VARA. Thanks to the VARA, the clash between the New Left and the party establishment, which came to a climax at a party conference, was played out in front of a TV audience. ${ }^{54}$ Such criticism mainly came from letter writers of an older generation, who had experienced national socialism and occupation. They championed a definition of politics as a serious business that was safe only in the hands of competent politicians, elected by the people, who discussed politics in parliament. Moreover, they perceived extra-parliamentary political action as a threat to the stability of the political system and often compared it with the political extremism of the interwar years. Finally, they expected politicians to have a sense of duty, to show restraint and be dedicated to reconstructing the country in the postwar years. Their hero was former party leader Willem Drees, prime minister between 1948 and 1958, who was also very critical of the role of the New Left within the party. ${ }^{55}$ The New Left posed a threat to his legacy and should therefore be contained as soon as possible. ${ }^{56}$

The PvdA also received letters from citizens of a younger generation who supported the cause of the New Left. They, in turn, complained about an older generation of party members who were standing in the way of the necessary rejuvenation the New Left was bringing to the party. ${ }^{57}$ One of these letter writers stated that the older generation "should accept, that their time has come, they have to make way for others. [...] Their old-fashioned ideas stand in the way of the progression of the party. That neither benefits us youngsters, nor the party." ${ }^{58}$ Seen from this perspective, the provocative, extra-parliamentary activities of the New Left offered an alternative to the establishment clogged-up channels of politics that were controlled by the establishment. ${ }^{59}$

Although these comments reveal a sense of political engagement among ordinary citizens, many citizens also addressed politicians with personal requests. Most of these requests came from people who belonged to the more

53 IISH, PvdA Archive, inv.nr. 373A, letters from H.S., 30 March 1969; unknown, 9 March 1969; J.V., 27 March 1969.

54 IISH, PvdA Archive, inv.nr. 366D, letter from E. de J., 23 March 1966.

$55 \quad$ Gaemers (2007) 73; Aerts (2003) 20.

56 IIsh, PvdA Archive, inv.nr. 373A, letter from A. van L., 12 March 1969.

57 IIsh, PvdA Archive, inv.nr. 374A, letter from H.L. jr., 16 Feb. 1970.

$5^{8}$ IIsh, PvdA Archive, inv.nr. 367B, letter from E.A., 23 Feb.1967: "[z]e moeten weten, dat voor hen de tijd gekomen is en dat ze plaats moeten maken voor anderen. [...] met hun ouderwetse ideeën remmen ze vooruitgang in de partij. Daar zijn wij niet bij gebaat en noch minder de partij" [sic]. 
vulnerable groups in society such as the elderly, disabled persons, and unemployed people. The Partij van de Arbeid was known to defend their interests and the party had indeed delivered an important contribution to the construction of the postwar welfare state with social services that were provided by the General Pensions Act (AOW, 1956), the Social Security Act (ABW, 1965), and the Disability Insurance Act (WAO, 1966). ${ }^{60}$ Against this background, citizens directed their letters at the PvdA to show the shortcomings of the existing package of social services. ${ }^{61}$

By turning to politicians, these letter writers bridged the distance between their peripheral social position and the centre of political decision making. ${ }^{62}$ Doing so, they were engaging in a long-established practice of communication between the elite and the people that can be characterised as a clientelistic exchange. Citizens offered party membership and their support at the ballot box and now expected something in return. A schoolteacher who had recently lost her job and blamed this on the local branch of the Partij van de Arbeid threatened to "turn my back on the Partij van de Arbeid" and switch sides to the party that was willing to give back her job. ${ }^{63}$ Citizens also tried to make their case stronger by claiming to defend the interests of a particular group of people, such as the elderly, the disabled, or the unemployed. They linked their case to the PvdA by reminding the party of the fact that it claimed to defend the interest of vulnerable groups in society. ${ }^{64}$

How did politicians respond to such interventions? As the American sociologist Leila Sussmann has pointed out in her study of the letters the American president Franklin D. Roosevelt received, understanding how politicians reacted to letters from ordinary citizens starts with an exploration of how the receiver valued the incoming mail. ${ }^{65}$ Upon arrival in the mailbox of the headquarters of the Partij van de Arbeid in Amsterdam, the letters went through a thorough administrative procedure. A special staff opened the letters, read them and made sure to forward them to the appropriate person within the party. To this end, a note was attached to each letter that contained its administrative number, date of arrival, and the coded abbreviation of the office or official responsible for answering the letter. ${ }^{66}$ In most cases, a copy of the answer was attached to the incoming letter and subsequently filed. The fact that

\footnotetext{
60 Schuyt (2013) 13.

61 IISH, PvdA Archive, inv.nr. 366D, letter from G.S., 8 Oct. 1965.

62 Fenske (2013) 71; Van Daalen (1987) 24.

63 IISH, PvdA Archive, inv.nr. 367 E, letter from A.S., 30 Sept. 1969.

64 Den Uyl (1978) 126; IISH, PvdA Archive, inv.nr. 365E, letter from A.D., 9 Sept. 1965.

65 Sussmann (1956) 10.

66 IISH, PvdA Archive, inv.nr. 487C, letter to G.N., 21 March 1967.
} 
the Partij van de Arbeid valued the mail they received also speaks from the nature of the answer people received to their letter. People hardly ever received a generic response, but a unique, personalised letter.

What effect did these letters have? Michaela Fenske has argued that these letters have an interruptive potential: the letters indeed prompted politicians to reflect on the impact of politics - in terms of policy making, laws, rules, and procedures - on the lives of ordinary citizens and on their role, as representatives of the people, in defending the interests of the people. ${ }^{67}$ On several occasions, specific requests resulted in political action on part of the politician: party chairman and MP Tans for instance addressed questions to the Minister for Education after receiving a complaint by mail about the position of teachers working on a temporary contract. ${ }^{68}$ Impressed by a letter he had received from a lonely, disabled woman, Vondeling asked fellow party member and tvjournalist Marcel van Dam to pay attention to the issue of social isolation in his television programme The OMBUdSMAn 'De Ombudsman'. ${ }^{9}$ This, of course, did not mean that politicians were willing to satisfy all the requests they received. They took requests seriously, but they did not hesitate to explain to citizens that their inquiries had made clear that nothing could be done, or that a request was unfounded or unreasonable. ${ }^{70}$ As far as the letters about the rise of the New Left were concerned, Tans and Vondeling in general tried to calm things down. People, mainly of an older generation, who were worried about the impact of the New Left, were told that the party needed to "stay in sync with the intellectual, younger generation." Extra-parliamentary activities did not threaten parliamentary democracy, they argued, but should be embraced as tools to counter political indifference and ignorance among the youth. ${ }^{71} \mathrm{Fi}$ nally, in general the letters addressed to the PvdA show that politicians and the people engaged in a meaningful form of interaction through and exchange of ideas and opinions, expectations, and justifications.

\footnotetext{
$67 \quad$ Fenske (2013) 21.

68 Aanhangsel Handelingen II 1965/1966, nr. 385; IISH, PvdA Archive, inv.nr. 366B, letter from A.P. Brandes, 15 March 1966; see also: IIsH, PvdA Archive, inv.nr. 367B, letter to Ph.J. van der M., 23 Aug. 1967.

69 IISH, PvdA Archive, inv.nr. 375A, letter to M.P. van Dam, 15 Sept. 1970.

70 See for instance IIsh, PvdA Archive, inv.nr. 365A,J. S.-S., 24 June 1965; Van de Griend (2017).

71 IISH, PvdA Archive, inv.nr. 374C, letter to M. van V., 2 July 1970; IISH, PvdA Archive, inv.nr. 374B, letter to A. K.-K., 27 March 1970.
} 


\section{Popular Politics: An Agenda for Future Research}

The letters people sent to politicians are only one element in a far broader repertoire of popular political engagement that we have aimed to outline in this chapter. How might historians go about exploring this repertoire? How can we integrate the practices of popular politics in our understanding of postwar political history? The letters provide an excellent angle to respond to Jon Lawrence's call to study the interaction between the formal and informal world of politics. We, however, need to be aware of the fact that we are dealing with a rather unmediated practice of interaction. Letters are the odd one out in a broader repertoire of highly mediated practices of popular politics. Studying popular politics therefore requires historians to also study the nature of this mediatisation.

Among media and communication scientists, studying the articulation of popular views on politics through the mass media has developed into a very prominent area of research. ${ }^{72}$ These scholars, however, do not offer a historical contextualisation of their research results, have mainly focused on the opportunities for popular agency in the Internet age, and tend to assume that "the public as a potentially empowered, active and participating force" is the hallmark of recent years. ${ }^{73}$ The few studies that offer a historical perspective on the interaction between politics and the mass media in the postwar years often treat citizens as the passive consumers of information presented to them through the media, as the audience of a mass-mediatised performance of politics. ${ }^{74}$ It is up to historians to integrate "the voice of the people" in research on the interaction between politics and the media.

One way to do so is by, first, deconstructing the communicative practices through which citizens voiced their political opinion in newspapers, on radio, and on television. This requires historians to pay attention to the different formats and modes of communication through which the voice of the people was mediated, such as letters-to-the-editor and street interviews. The feasibility of such research is enhanced by the availability of digital newspaper databases and repositories of radio and television broadcasts. ${ }^{75}$ The second step involves an analysis of the content of the opinions voiced by ordinary citizens through these channels. Given the availability of digital data, historians should consider using tools and techniques of digital humanities in order to carry out

\footnotetext{
72 Liesbet van Zoonen (2005); Bakker (2013); Brants (2011) 126-45.

73 Brants (2017) 403.

74 Manin (1997); Habermas (1962).

75 For the Dutch case, historians can use the Delpher newspaper database $<\mathrm{http}$ ://www. delpher.nl > and the Clariah Media Suite: <http://mediasuite.clariah.nl/ >.
} 
a longitudinal content analysis of the voice of the people. Third, such an approach should also include a discussion of how mass media actors (journalists and broadcasters) have reflected on their role in creating communicative practices through which the voice of the people was articulated: what were their motivations to do so? Fourth and finally, the analysis stretches out to the reception of "the voice of the people" by politicians. How did they process popular articulations of political representation? To what extent were politicians judged based on their ability to interact with ordinary citizens? What impact did the communicative practices of popular engagement have on styles of political leadership? Taken together, the answers to these questions might help us to truly incorporate "ordinary citizens" and their shifting perceptions and expectations of "politics" and the people who represented them politically in our understanding of postwar political history.

\section{Bibliography}

Aerts, R., "Emotie in de politiek: over politieke stijlen in Nederland sinds 1848," in Jaarboek Parlementaire Geschiedenis (Amsterdam, 2003), 12-25.

Bakker, T., Citizens as political participants. The myth of the active online audience? (Amsterdam, 2013).

Beyen, M., "Clientelism and politicization. Direct interactions between deputies and "ordinary citizens" in France, ca. 1890 - ca. 1940," in Temp 8 (2014), 17-32.

Black, L., Redefining British Politics. Culture, Consumerism and Participation, 1954-70 (Basingstoke, 2010).

Black, L., "Popular politics in Modern British History," in The Journal of British Studies 40, no. 3 (2001), 431-445.

Brants, K., and P. van Praag, "Beyond Media Logic," in Journalism Studies 18, no. 4 (2017), 395-408.

Brants, K., and K. Voltmer, Political Communication in Postmodern Democracy: Challenging the Primacy of Politics (Basingstoke, 2011).

Brants, K., "Opgejaagd door Ceberus. De moeizame mediatisering van de politieke communicatie," in J. Bardoel, C. Vos, F. van Vree, and H. Wijfes (eds.), Journalistieke cultuur in Nederland (Amsterdam, 2009), 85-100.

Brants, K., and P. van Praag, "Signs of Media Logic: Half a Century of Political Communications in the Netherlands," in Javnost/The Public 13, no. 1 (2006), 25-40.

Campbell, A., G. Gurin, and W.E. Miller, The Voter Decides (New York, 1954).

Cate, L. ten, "Tussen twee congressen: van de politiek naar de mensen," in Opinie:veertiendaags orgaan van de Partij van de Arbeid 22, no. 3 (1967), 6-7. 
Conway, M., "Democracy in Postwar Western Europe: The Triumph of a Political Model," in European History Quarterly 32 no. 1 (2002), 59-84.

Daalen, R. van, Klaagbrieven en gemeentelijk ingrijpen Amsterdam, 1865-1920 (Amsterdam, 1987).

Davis, B., "What's Left? Popular Political Participation in Postwar Europe," in The American Historical Review 113, no. 2 (2008), 363-390.

Dixhoorn, A. van, De stem des volks. Publieke opinie, opinieonderzoek en democratie (Den Haag, 2006).

Eakin, P.J., How Our Lives Become Stories: Making Selves (Ithaca, 1999).

Eley, G., Forging Democracy. The History of the Left in Europe, 1850-2000 (Oxford, 2002).

Fenske, M., Demokratie erschreiben. Bürgerbriefe und Petitionen als Medien politischer Kultur 1950-1974 (Frankfurt am Main, 2013).

Fielding, S., A State of Play. British Politics on Screen, Stage and Page, from Anthony Trollope to The Tick of It (London, 2014).

Ginderachter, M. van, "If your Majesty would only send me a little money to help buy an elephant': Letters to the Belgian Royal Family (1880-1940)," in M. Lyons (ed.), Ordinary Writings, Personal Narratives. Writing Practices in the 19th and early 2othcentury Europe (Bern, 2007), 69-83.

Gaemers, J., "Willem Drees privé verklaard," in H. Renders and G. Voerman (eds.), Privé in de Politieke Biografie (Amsterdam, 2007), 67-82.

Griend, V. van de, "Burgerpost met pantoffels voor PvdA-voorzitter Ko Suurhoff, maart 1961," in Jaarboek Parlementaire Geschiedenis (Amsterdam, 2017), 97-100.

Griend, V. van de, "De pen van het volk. Welke rol vervulde de burgerbrief in het contact tussen de PvdA en haar kiezers tussen 1966 en 1971?," (Master's thesis, Radboud University Nijmegen, 2016).

Habermas, J., Strukturwandel der Öffentlichkeit. Untersuchungen zu einer Kategorie der bürgerlichen Gesellschaft (Neuwied, 1962).

Hauser, G.A., Vernacular Voices: The Rhetoric of Publics and Public Spheres (Columbia, 1999)

Hoogerwerf, A., "De Nederlandse staatsburger: toeschouwer of medespeler? Partijactiviteit en opvattingen over politieke participatie," in Sociologische Gids 14, no. 5 (1967), 293-314.

Hunt, L., Politics, Culture and Class in the French Revolution (Berkeley, 1984).

Igo, S.E., The Averaged American. Surveys, Citizens, and the Making of a Mass Public (Cambridge, Eng., 2007).

Jong, W. de, Van wie is de burger? Omstreden democratie in Nederland 1945-1989 (Nijmegen, 2014).

Kaal, H., "De cultuur van het televisiedebat. Veranderende percepties van de relatie tussen media en politiek, 196o-heden," in Tijdschrift voor Geschiedenis 127, no. 1 (2014), 293-316. 
Kaal, H., "Reconstructing Post-War Political Communities. Class, Religion and Political Identity Formation in the Netherlands, 1945-68," in H. Kaal and S. Couperus (eds.), (Re)Constructing Communities in Europe, 1918-1968. Senses of Belonging Below, Beyond and Within the Nation-State (London and New York, 2017), 217-237.

Kaal, H., "The voice of the people. Communicative practices of popular political engagement in the Netherlands, 1950s-1960s," in Archiv für Sozialgeschichte 58 (2018), 183-200.

Kennedy, J.C., Nieuw Babylon in aanbouw. Nederland in de jaren zestig (Amsterdam, 1995).

Lawrence, J., Electing our Masters: The Hustings in British Politics from Hogarth to Blair (Oxford, 2009).

Lawrence, J., "The Transformation of British Public Politics after the First World War," in Past\&Present 190 (2006), 185-216.

Lawrence, J., Speaking for the People: Party, Language and Popular Politics in England, 1867-1914. (Cambridge, Eng., 1998).

Manin, B., The principles of representative government (Cambridge, Eng., 1997).

Pitkin, H., The Concept of Representation (Berkeley, 1967).

Praag, P., van, Strategie en illusie. Elfjaar intern debat in de PvdA (1966-1977) (Amsterdam, 1991).

Rosanvallon, P., Democratic Legitimacy. Impartiality, Reflexivity, Proximity, translated by A. Goldhammer (Oxford, 2011).

Rosanvallon, P., Counter-Democracy. Politics in an Age of Distrust, trans. A. Goldhammer (Cambridge, Eng., 2008).

Rosanvallon, P., La contre-démocratie. La politique à l'âge de la défiance (Paris, 2006).

Saward, M., "Governance and the transformation of political representation," in J. Newman (eds.), Remaking Governance: Peoples, Politics and the Public Sphere (Bristol, 2005), 179-196.

Saward, M., "The Representative Claim," in Contemporary Political Theory 5 (2006), 297-318.

Saward, M., The representative Claim (Oxford, 2010).

Schuyt, K., Noden en wensen. De verzorgingsstaat gezien als een historisch fenomeen (Rotterdam, 2013).

Steinmetz, W., and H-G. Haupt, "The Political as Communicative Space in History: The Bielefeld Approach," in W. Steinmetz, I. Gilcher-Holtey, and H-G. Haupt (eds.), Writing Political History (Frankfurt am Main, 2013), 11-33.

Steinmetz, W., (ed.), Political Languages in the Age of Extremes (Oxford, 2011).

Street, J., "Celebrity Politicians: Popular Culture and Political Representation," in The British Journal of Politics and International Relations 6, no. 4 (2004), 435-452.

Strinati, D., and S. Wagg (eds.), Come on Down? Popular Media Culture in Post-war Britain (London, 1992). 
Sussmann, L.A., Dear FD R: A Study of Political Letter Writing (Totawa, 1963).

Sussmann, L.A., "FDR and the White House Mail," in The Public Opinion Quarterly 20, no. 1 (1956), 5-16.

Uyl, J. den, "De kwaliteit van het bestaan," in J. den Uyl (ed.) Inzicht en uitzicht. Opstellen over politiek en economie (Amsterdam, 1978), 116-127.

Vernon, J., Politics and the People: A Study in English Political Culture, c. 1815-1867 (Cambridge, Eng., 1993).

Zimmermann, H-P., "Lebenswelt und Politik. Bürgerbriefe an Helmut Schmidt 1982," in P. Janich (ed.), Humane Orientierungswissenschaft. Was leisten verschiedene Wissenschaftskulturen für das Verständnis menschlicher Lebenswelt (Würzburg, 2008), 203226.

Zoonen, L. van, Entertaining the Citizen: When Politics and Popular Culture Converge (Lanham, 2005). 